\title{
Cerium-photocatalyzed aerobic oxidation of benzylic alcohols to aldehydes and ketones
}

\author{
Girish Suresh Yedase ${ }^{\ddagger 1}$, Sumit Kumar ${ }^{\ddagger 1}$, Jessica Stahl² ${ }^{2}$ Burkhard König ${ }^{2}$ \\ and Veera Reddy Yatham ${ }^{* 1}$
}

\section{Letter}

\section{Address:}

${ }^{1}$ School of Chemistry, Indian Institute of Science Education and Research, Thiruvananthapuram (IISER-TVM) 695551, India and ${ }^{2}$ Institut für Organische Chemie, Fakultät für Chemie und Pharmazie, Universität Regensburg, Universitätstraße 31, D-93053 Regensburg, Germany

Email:

Veera Reddy Yatham* - reddy@iisertvm.ac.in

* Corresponding author $\ddagger$ Equal contributors

Keywords:

alcohol; aldehydes; cerium; oxidation; ketones; visible light

\author{
Beilstein J. Org. Chem. 2021, 17, 1727-1732. \\ https://doi.org/10.3762/bjoc.17.121 \\ Received: 22 May 2021 \\ Accepted: 16 July 2021 \\ Published: 23 July 2021 \\ Associate Editor: D. Y.-K. Chen \\ (c) 2021 Yedase et al.; licensee Beilstein-Institut. \\ License and terms: see end of document.
}

\section{Abstract}

We have developed a cerium-photocatalyzed aerobic oxidation of primary and secondary benzylic alcohols to aldehydes and ketones using inexpensive $\mathrm{CeCl}_{3} \cdot 7 \mathrm{H}_{2} \mathrm{O}$ as photocatalyst and air oxygen as the terminal oxidant.

\section{Introduction}

The selective oxidation of alcohols to carbonyl compounds $[1,2]$ is an important process for producing a wide range of value-added fine chemicals [3-6]. In the traditional oxidation process stoichiometric amounts of oxidants such as $\mathrm{Br}_{2}, \mathrm{MnO}_{2}$, hypervalent iodine reagents, chromium-based reagents, activated dimethyl sulfoxide, $\mathrm{KMnO}_{4}$, $\mathrm{OsO}_{4}$, or metal-based catalysts and peroxide were used [7-17]. Most of these protocols produce harmful waste and some of the oxidizing reagents are considered toxic [7-17]. In order to overcome the limitations, various homogeneous and heterogeneous catalytic oxidation systems have been reported. Aerobic oxidation is particularly attractive as it allows the transformations under mild reaction conditions with molecular oxygen acting as the terminal oxidant
[13-33]. Most aerobic oxidation reactions utilize either metal complexes and nanoparticles or persistent radical reagents as catalysts [21].

In the past ten years, visible light-induced photocatalysis has emerged as an alternative to the classical conventional synthetic methods to construct carbon-carbon and carbon-heteroatom bonds [34-37]. As a mild, efficient, and environmentally friendly approach it has the potential to unlock unique reactions that are previously inaccessible under thermal conditions. Significant advances were made for the oxidation of benzylic alcohols by using metal-based photocatalysts [38-46] and metal-free photocatalysis [47-53] in combination with various oxidants, 
such as TBHP and DDQ [54,55]. However, the reported methods require either specific nanoparticle catalysts [39-42] or the catalytic method is limited to electron-rich or electronneutral benzylic alcohols [56]. An operationally simple method avoiding waste and potentially toxic transition-metal catalysts that is able to convert any benzylic alcohol selectively to the aldehyde or ketone is still desirable. Recently, cerium photocatalysis was introduced as a robust alternative to generate oxygen or carbon-centered radicals under mild reaction conditions [5764]. $\mathrm{CeCl}_{3}$ reacts via ligand-to-metal charge transfer generating oxygen-centered radicals, that lead to carbon-centered radicals through intra/intermolecular hydrogen atom transfer (HAT) processes, radical decarboxylative or radical deformylation [5759]. In continuation of our research interest on visible-lightdriven cerium photocatalysis $[59,65]$, we herein report a mild aerobic photocatalytic oxidation of benzylic alcohols to aldehydes and ketones using $10 \mathrm{~mol} \% \mathrm{CeCl}_{3} \cdot 7 \mathrm{H}_{2} \mathrm{O}$ (Scheme 1).

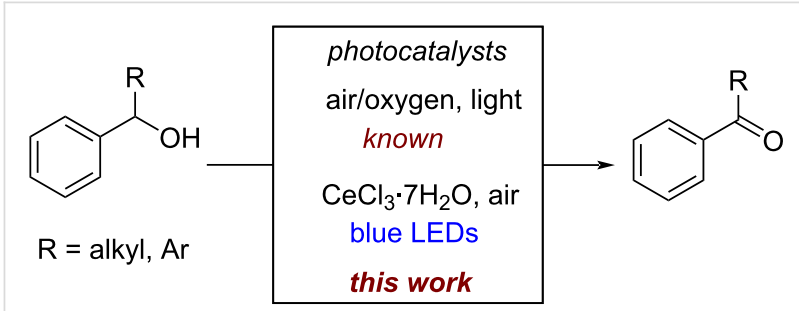

Scheme 1: Photocatalyzed aerobic oxidation of aromatic alcohols

\section{Results and Discussion}

A variety of reaction parameters was tested during the optimization of the reaction with 4-iodobenzyl alcohol (1a) as the model substrate and air as the oxidant (Table 1). The best results were found using $10 \mathrm{~mol} \% \mathrm{CeCl}_{3} \cdot 7 \mathrm{H}_{2} \mathrm{O}$ as a photocatalyst and $10 \mathrm{~mol} \%$ of $\mathrm{NaHCO}_{3}$ as a base in $\mathrm{CH}_{3} \mathrm{CN}$ under blue LED irradiation at $50{ }^{\circ} \mathrm{C}$ for $35 \mathrm{~h}$ giving compound $2 \mathrm{a}$ in $65 \%$ isolated yield (Table 1, entry 1 ). The product formation was reduced upon employing other cerium salts (Table 1, entries 2 and 3). Also, replacing $\mathrm{NaHCO}_{3}$ by other bases such as $\mathrm{K}_{2} \mathrm{CO}_{3}$ and $\mathrm{Na}_{2} \mathrm{CO}_{3}$ resulted in lower yields $(30-40 \%)$ of product 2a (Table 1, entries 4 and 5). In the absence of a base the reaction afforded product $\mathbf{2 a}$ in $40 \%$ yield (Table 1 , entry 6 ). The reaction worked with similar efficiency in $\mathrm{CHCl}_{3}$ and DMF (Table 1, entries 7 and 8), while other solvents such as toluene and EtOAc gave 2a in moderate yields (Table 1, entries 9 and 10). THF was found to be less effective in this oxidation reaction (Table 1, entry 11). Performing the reaction at $35{ }^{\circ} \mathrm{C}$ gave 2a in a moderate yield of $35 \%$ (Table 1, entry 12). Employing an external oxidant such as $\left(\mathrm{NH}_{4}\right)_{2} \mathrm{~S}_{2} \mathrm{O}_{8}$ instead of air diminished the yield (Table 1, entry 13). The substitution of air with a balloon of oxygen afforded 2a in 25\% yield (Table 1, entry 14), while employing an argon atmosphere led to only trace amounts of the product (Table 1, entry 15). Additionally, control experiments indicated that catalytic amounts of the cerium salt, air atmosphere and light irradiation were necessary for the reaction to occur (Table 1, entries 16 and 17).

Table 1: Optimization of the reaction conditions. ${ }^{a}$

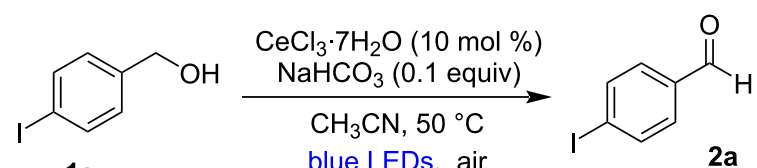

$1 \mathbf{a}$

blue LEDs, air

$2 a$

\begin{tabular}{|c|c|c|}
\hline entry & deviation from standard conditions & $2 \mathbf{a}(\%)^{\mathrm{b}}$ \\
\hline 1 & none & $70(65)^{c}$ \\
\hline 2 & $\mathrm{CeCl}_{3}$ instead of $\mathrm{CeCl}_{3} \cdot 7 \mathrm{H}_{2} \mathrm{O}$ & 60 \\
\hline 3 & $\begin{array}{l}\left(n-\mathrm{Bu}_{4} \mathrm{~N}\right)_{2} \mathrm{Ce}^{\mathrm{IV}} \mathrm{Cl}_{6} \text { instead of } \\
\mathrm{CeCl}_{3} \cdot 7 \mathrm{H}_{2} \mathrm{O}\end{array}$ & 42 \\
\hline 4 & $\mathrm{~K}_{2} \mathrm{CO}_{3}$ instead of $\mathrm{NaHCO}_{3}$ & 40 \\
\hline 5 & $\mathrm{Na}_{2} \mathrm{CO}_{3}$ instead of $\mathrm{NaHCO}_{3}$ & 30 \\
\hline 6 & without base & 40 \\
\hline 7 & $\mathrm{CHCl}_{3}$ instead of $\mathrm{CH}_{3} \mathrm{CN}$ & 56 \\
\hline 8 & DMF instead of $\mathrm{CH}_{3} \mathrm{CN}$ & 60 \\
\hline 9 & toluene instead of $\mathrm{CH}_{3} \mathrm{CN}$ & 30 \\
\hline 10 & EtOAc instead of $\mathrm{CH}_{3} \mathrm{CN}$ & 21 \\
\hline 11 & THF instead of $\mathrm{CH}_{3} \mathrm{CN}$ & 5 \\
\hline 12 & at $35^{\circ} \mathrm{C}$ instead of $50^{\circ} \mathrm{C}$ & 35 \\
\hline 13 & $\begin{array}{l}\text { with } 2.0 \text { equiv of }\left(\mathrm{NH}_{4}\right)_{2} \mathrm{~S}_{2} \mathrm{O}_{8} \text { instead } \\
\text { of air }\end{array}$ & 28 \\
\hline 14 & with $\mathrm{O}_{2}$ balloon instead of air & 25 \\
\hline 15 & under argon instead of air & trace \\
\hline 16 & without $\mathrm{CeCl}_{3} \cdot 7 \mathrm{H}_{2} \mathrm{O}$ & 0 \\
\hline 17 & without light & trace \\
\hline
\end{tabular}

aStandard conditions: $1 \mathbf{1 a}(0.2 \mathrm{mmol}), \mathrm{CeCl}_{3} \cdot 7 \mathrm{H}_{2} \mathrm{O}(10 \mathrm{~mol} \%)$, $\mathrm{NaHCO}_{3}(10 \mathrm{~mol} \%), \mathrm{CH}_{3} \mathrm{CN}(0.1 \mathrm{M})$ at $50{ }^{\circ} \mathrm{C}, 455 \mathrm{~nm}$ blue LED for $35 \mathrm{~h}$. bNMR yields using trimethoxybenzene as internal standard. clsolated yield.

With the optimized reaction parameters in our hands, we next explored the substrate scope of the reaction. As shown in Scheme 2, a broad range of primary and secondary benzylic alcohols was converted into the corresponding aldehydes and ketones. Various electron-withdrawing para-halo-substituted benzylic alcohols 1a-d were tested under the optimized reaction conditions and gave the corresponding halo-substituted benzaldehydes $\mathbf{2 a - d}$ in good yields. The oxidation of simple benzyl alcohol (1e) under our reaction conditions gave benzaldehyde (2e) in 55\% yield. A variety of electron-donating para-substituted benzyl alcohols (1f-h) gave lower isolated yields of the corresponding benzaldehydes $\mathbf{2 f}-\mathbf{h}$. Our methodology tolerates a variety of functional groups containing benzylic alcohols such as $-\mathrm{OH}(\mathbf{1 h}),-\mathrm{CN}(\mathbf{1 i}),-\mathrm{NO}_{2}(\mathbf{1 j})$, methyl ester $(\mathbf{1 k})$, and benzyloxy $(\mathbf{1 v})$ to produce the corresponding alde- 
<smiles>[R]C(O)c1cc[R]cc1</smiles>

1a

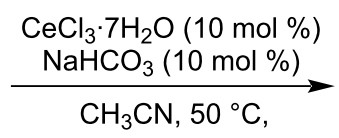

blue LEDs, air<smiles>[R]C(=O)c1cc[R]cc1</smiles>

$2 a$

$\mathrm{R}^{1}=\mathrm{H}, \mathrm{Ar}$, alkyl

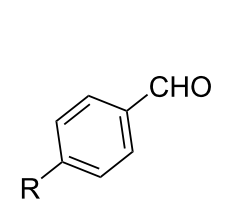

2a, $R=I, 65 \%, 40 \%^{a}$

2b, $R=F, 63 \%$

2c, $\mathrm{R}=\mathrm{Cl}, 67 \%$

2d, $\mathrm{R}=\mathrm{Br}, 76 \%$

2e, $\mathrm{R}=\mathrm{H}, 55 \%^{\mathrm{b}}$

2f, $R=M e, 48 \%^{b}$

2g, R $=\mathrm{OMe}, 37 \%^{\mathrm{c}}$

2h, $\mathrm{R}=\mathrm{OH}, 34 \%^{\mathrm{c}}$

2i, $\mathrm{R}=\mathrm{CN}, 58 \%$

2j, $\mathrm{R}=\mathrm{NO}_{2}, 55 \%$

2k, R = COOMe, $57 \%$
2I, $R=F, 60 \%$

$2 \mathrm{~m}, \mathrm{R}=\mathrm{Cl}, 63 \%$

2n, $\mathrm{R}=\mathrm{Ph}, 25 \%^{\mathrm{c}}$

2o, $\mathrm{R}=\mathrm{Me}, 59 \% \mathrm{~b}$

$2 p, R=O M e, 40 \% c$

2q, $R=O P h, 64 \%$

2r, $R=S P h, 61 \%$

2s, $R=O(4-C I P h), 67 \%$<smiles>[R]c1cccc(C=O)c1</smiles>

2t, $\mathrm{R}=\mathrm{Br}, 60 \%$

$2 \mathrm{u}, \mathrm{R}=\mathrm{NO}_{2}, 58 \%$

2v, $\mathrm{R}=\mathrm{OCH}_{2} \mathrm{Ph}, 56 \%$<smiles>O=Cc1ccc(Cl)cc1Cl</smiles>

2w, $70 \%$<smiles>O=C1CCCc2ccccc21</smiles>

2ab, $55 \%^{\mathrm{b}}$<smiles>O=Cc1ccc(Br)s1</smiles>

$2 x, 80 \%$<smiles>O=C(c1ccccc1)c1ccccc1</smiles>

2ac, $56 \%^{\text {b }}$<smiles>O=Cc1ccc2ccccc2c1</smiles>

$2 y, 61 \%$ b<smiles>COc1ccc(C(=O)c2ccccc2)cc1</smiles>

2ad, $51 \%^{b}$<smiles>[R]c1ccc(C(C)=O)cc1</smiles>

2z, $\mathrm{R}=\mathrm{H}, 60 \%^{\mathrm{b}}$

2aa, $\mathrm{R}=\mathrm{CH}_{3}, 70 \%$ b<smiles>O=C(c1ccccc1)c1ccccc1Cl</smiles>

$2 a e, 53 \%^{b}$

unsuccessful substrates ${ }^{C}$<smiles>OCCCc1ccccc1</smiles>

2af, $0 \%$<smiles>CC(C)=CCC/C(C)=C/CO</smiles>

2ag, $5 \%$<smiles>OC/C=C/c1ccccc1</smiles>

2ah, $7 \%$

Scheme 2: Substrate scope. Reaction conditions as given in Table 1 (entry 1). Yields are isolated yields, average of at least two independent runs. Notes: ${ }^{a}$ the reaction was carried using $4.3 \mathrm{mmol}$ of $1 \mathrm{a}$ and reaction time was $72 \mathrm{~h} ;{ }^{\mathrm{b}} 42 \mathrm{~h}$ reaction time; ${ }^{\mathrm{c}} 48 \mathrm{~h}$ reaction time.

hydes (2h-k and $\mathbf{2 v}$ ) in moderate yields. Next, electronically different ortho-substituted benzylic alcohols were tested and 2-fluoro (11) and 2-chloro (1m) benzyl alcohols gave the aldehydes $\mathbf{2 l}$ and $\mathbf{2 m}$ in good yields. The $o$-phenyl-substituted benzylic alcohol (1n) afforded biphenyl-2-carbaldehyde (2n) in only low yield $(25 \%)$ probably due to steric reasons. The $o$-methyl (10) and $o$-methoxy (1p) benzylic alcohols yielded the corresponding benzaldehydes $\mathbf{2 o}$ and $\mathbf{2 p}$ in moderate yields and to our surprise we did not observe any oxidation of the methyl or methoxy groups via hydrogen atom transfer processes [57] Interestingly, we found that a variety of ortho-phenoxy-substituted benzylic alcohols (1q, 1s) were oxidized under our reaction conditions giving the corresponding aldehydes $(\mathbf{2 q}, \mathbf{2} \mathbf{s})$ in good yields. Also, the meta-substituted benzylic alcohols 1t-v reacted to the corresponding benzaldehydes in good yields in our reaction conditions. Ortho/para-disubstituted benzylic alcohol $\mathbf{1 w}$ gave 2,4-dichlorobenzaldehyde (2w) in 70\% yield. The sulfur-containing compounds 4-(phenylthio)benzyl alcohol (1r) and the heterocyclic compound thiophene-2-ylmethanol (1x) gave the corresponding aldehydes $2 \mathbf{r}$ and $\mathbf{2 x}$ in 61 and $80 \%$ yield, respectively. Finally, 2-naphthylmethanol (1y) was subjected to the reaction conditions and gave 2-naphthaldehyde (2y) in good yield (61\%).

Next, the scope of secondary benzylic alcohols was tested in our reaction conditions. Substituted 1-phenylethanols such as 
1z, 1aa, tetralol (1ab), diphenyl methanol (1ac) and derivatives thereof with substituents of different electronic nature such as 1ad and 1ae gave the ketones 2z, 2aa, 2ab, 2ac, 2ad, and 2ae in good yields. However, the primary aliphatic alcohol 3-phenylpropanol (1af) did not provide the desired aldehyde at all, and allylic alcohols such as geraniol (1ag) and cinnamyl alcohol (1ah) afforded the aldehydes 2ag and 2ah in very low yields (5 and $7 \%$, respectively). In addition, when the mixture of 3-phenylproponol (1ah) and 3-bromobenzylic alcohol (1t) was subjected to the standard reaction conditions, we observed the selective oxidation of the benzylic alcohol giving the expected product in $44 \%$ yield (Scheme 3 ).

The efficiency of this cerium-photocatalyzed aerobic oxidation of alcohols prompted us to conduct some preliminary mechanistic studies (Figure 1). As anticipated, the ON/OFF irradiation experiments confirmed that our reaction required a continuous blue light irradiation (see Supporting Information File 1). The inhibition of the catalytic cycle upon the addition of TEMPO revealed that the reaction proceeds through radical intermediates. Next, we carried out UV-vis monitoring experiments in order to verify whether the interaction with the substituted benzyl alcohols and $\mathrm{Ce}^{\mathrm{IV}}$ could lead to a ligand-to-metal charge transfer (LMCT) process, which reduces the $\mathrm{Ce}^{\mathrm{IV}}$ species to $\mathrm{Ce}^{\mathrm{III}}$, similarly as reported by Zuo and co-workers [57]. We chose $\left(n-\mathrm{Bu}_{4} \mathrm{~N}\right)_{2} \mathrm{Ce}^{\mathrm{IV}} \mathrm{Cl}_{6}$ as the $\mathrm{Ce}^{\mathrm{IV}}$ source to ensure a sufficient solubility in organic solvents and to facilitate the detection of the species. The $\mathrm{Ce}^{\mathrm{IV}}(\mathrm{OBn}) \mathrm{Cl}_{n}$ complex was prepared by mixing the $\left(n-\mathrm{Bu}_{4} \mathrm{~N}\right)_{2} \mathrm{Ce}^{\mathrm{IV}^{2}} \mathrm{Cl}_{6}$ complex with $\mathrm{BnOH}$ under basic conditions. The UV-vis spectra of the $\mathrm{Ce}^{\mathrm{IV}}(\mathrm{OBn}) \mathrm{Cl}_{n}$ complex displayed a band resembling the LMCT band of known cerium-alkoxide complexes, showing considerable overlap with the blue LED region, thus suggesting that the $\mathrm{Ce}^{\mathrm{IV}}(\mathrm{OBn}) \mathrm{Cl}_{n}$ species could be photoexcited (Figure $\left.1 \mathrm{~A}\right)$. We then analyzed UV-vis spectra of the $\mathrm{Ce}^{\mathrm{IV}}(\mathrm{OBn}) \mathrm{Cl}_{n}$ complex recorded after irradiation with blue light at different time intervals. As shown in Figure 1A, the absorption spectrum of the $\mathrm{Ce}^{\mathrm{IV}}(\mathrm{OBn}) \mathrm{Cl}_{n}$ complex gradually shifted from $\lambda_{\max }=375 \mathrm{~nm}$ to $\lambda_{\max }=325 \mathrm{~nm}$ upon irradiation, which indicates a photoinduced $\mathrm{Ce}^{\mathrm{IV}}-\mathrm{OBn}$ homolytic cleavage to generate a $\mathrm{Ce}^{\mathrm{III}} \mathrm{com}$ plex and a benzyloxy radical. Although the exact catalytic cycle of our reaction remains to be elucidated, we propose a plausible reaction mechanism based on our observations and known literature precedents (Figure 1B) [57,59,66-69]. Under aerobic conditions the catalytic $\mathrm{Ce}^{\mathrm{III}}(\mathrm{OBn}) \mathrm{L}_{n}$ species $\mathbf{I}$ (in situ derived by the reaction of $\mathrm{CeCl}_{3}\left(\mathrm{Ce}^{\mathrm{III}} \mathrm{L}_{n}\right)$ with the substrate benzyl alcohol, $\mathrm{BnOH}$ ) could be oxidized to $\mathrm{L}_{n} \mathrm{Ce}^{\mathrm{IV}}-\mathrm{OBn}$ complex II [67-69]. During this process $\mathrm{O}_{2}$ is converted into a superoxide radical anion $\mathrm{O}_{2}{ }^{--}$. Photolysis of the $\mathrm{Ce}^{\mathrm{IV}}-\mathrm{OBn}$ complex (II), leads to the formation of the corresponding benzyloxy radical

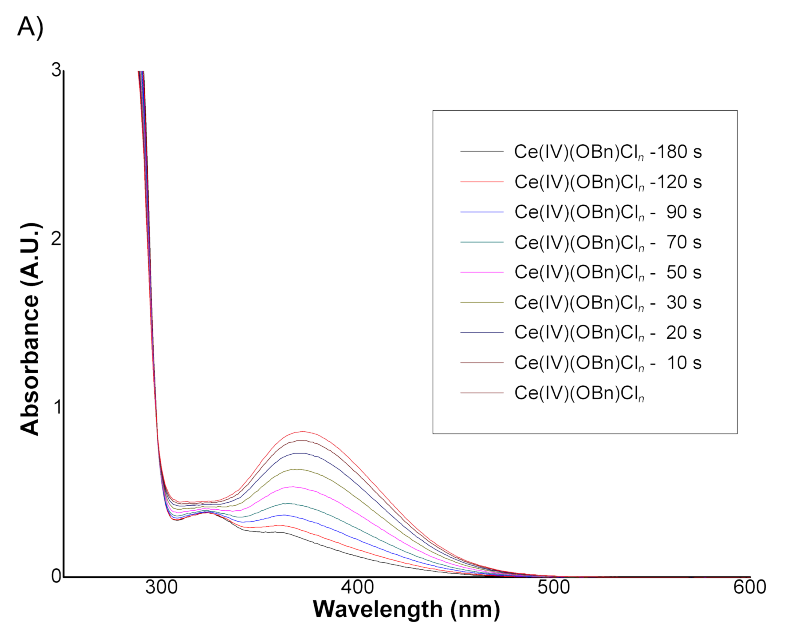

B)

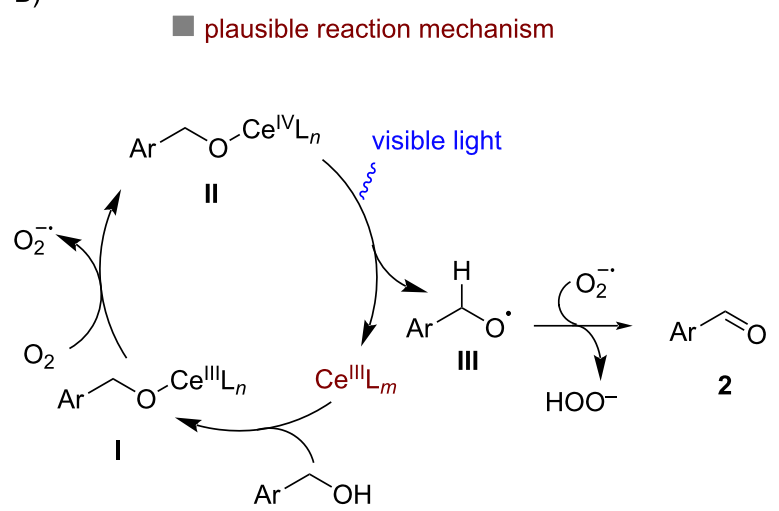

Figure 1: Mechanistic studies. (A): UV-vis spectra of the $\mathrm{Ce}^{\mathrm{IV}}(\mathrm{OBn}) \mathrm{Cl}_{n}$ complex in $\mathrm{CH}_{3} \mathrm{CN}$ under blue light irradiation (0-180 s); (B): plausible reaction mechanism.<smiles>OCCCc1ccccc1</smiles>

1af<smiles>OCc1cccc(Br)c1</smiles>

1t

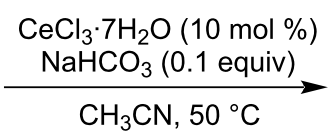

blue LEDs, air, $35 \mathrm{~h}$<smiles>O=Cc1cccc(Br)c1</smiles>

$2 \mathrm{t}$

Scheme 3: Selective oxidation of 3-bromobenzyl alcohol in the presence of 3-phenylpropanol. Compound 1af was recovered unchanged from the reaction mixture. 
(III) and regenerates the $\mathrm{Ce}^{\mathrm{III}}$ species. A further abstraction of a benzylic hydrogen atom by the peroxide radical then generates the final product 2 [48]. However, at this moment we cannot exclude the involvement of possible intermolecular HAT or 1,2HAT from the intermediate III to generate the product 2.

\section{Conclusion}

In summary, we have developed a catalytic aerobic oxidation of benzylic alcohols to the corresponding aldehydes without further oxidation and formation of benzoic acids. A variety of primary and secondary benzylic alcohols were converted into the corresponding aldehydes and ketones in good to moderate yields using commercially available and inexpensive $\mathrm{CeCl}_{3} \cdot 7 \mathrm{H}_{2} \mathrm{O}$ as a photocatalyst and air as an oxidant.

\section{Supporting Information}

\section{Supporting Information File 1}

Full experimental details, compound characterization, and copies of NMR spectra.

[https://www.beilstein-journals.org/bjoc/content/ supplementary/1860-5397-17-121-S1.pdf]

\section{Funding}

V.R.Y. acknowledges IISER-TVM for the financial support. GSY acknowledges the IISER TVM for the doctoral fellowship. JS thanks the Studienstiftung des Deutschen Volkes for a Ph.D stipend.

\section{ORCID ${ }^{\circledR}$ iDs}

Burkhard König - https://orcid.org/0000-0002-6131-4850 Veera Reddy Yatham - https://orcid.org/0000-0002-3967-5342

\section{References}

1. Tojo, G. Oxidation of Alcohols to Aldehydes and Ketones: A Guide to Current Common Practice; Springer Science \& Business Media: New York, NY, USA, 2006.

2. Wang, D.; Weinstein, A. B.; White, P. B.; Stahl, S. S. Chem. Rev. 2018, 118, 2636-2679. doi:10.1021/acs.chemrev.7b00334

3. Bäckvall, J.-E. Modern Oxidation Methods; Wiley-VCH: Weinheim, Germany, 2004

4. Dunn, P. J.; Wells, A. S.; Williams, M. T. Future trends for green chemistry in the pharmaceutical industry. In Green Chemistry in the Pharmaceutical Industry; Dunn, P. J.; Wells, A. S.; Williams, M. T., Eds.; Wiley-VCH: Weinheim, Germany, 2010; pp 333-355. doi:10.1002/9783527629688.ch16

5. Das, A.; Stahl, S. S. Angew. Chem., Int. Ed. 2017, 56, 8892-8897. doi:10.1002/anie.201704921

6. Kawahara, R.; Fujita, K.-I.; Yamaguchi, R. Angew. Chem., Int. Ed. 2012, 51, 12790-12794. doi:10.1002/anie.201206987

7. Friedrich, H. B. Platinum Met. Rev. 1999, 43, 94-102.
8. Omura, K.; Swern, D. Tetrahedron 1978, 34, 1651-1660. doi:10.1016/0040-4020(78)80197-5

9. Gorini, L.; Caneschi, A.; Menichetti, S. Synlett 2006, 948-950. doi:10.1055/s-2006-939045

10. Pfitzner, K. E.; Moffatt, J. G. J. Am. Chem. Soc. 1963, 85, 3027-3028. doi:10.1021/ja00902a036

11. Parikh, J. R.; Doering, W. v. E. J. Am. Chem. Soc. 1967, 89, 5505-5507. doi:10.1021/ja00997a067

12. Albright, J. D.; Goldman, L. J. Am. Chem. Soc. 1965, 87, 4214-4216. doi:10.1021/ja01096a055

13. Liu, R.; Liang, X.; Dong, C.; Hu, X. J. Am. Chem. Soc. 2004, 126, 4112-4113. doi:10.1021/ja031765k

14. ten Brink, G. J.; Arends, I. W. C. E.; Sheldon, R. A. Science 2000, 287 1636-1639. doi:10.1126/science.287.5458.1636

15. Mori, K.; Hara, T.; Mizugaki, T.; Ebitani, K.; Kaneda, K. J. Am. Chem. Soc. 2004, 126, 10657-10666. doi:10.1021/ja0488683

16. Markó, I. E.; Giles, P. R.; Tsukazaki, M.; Brown, S. M.; Urch, C. J. Science 1996, 274, 2044-2046. doi:10.1126/science.274.5295.2044

17. Li, B.; Gu, T.; Ming, T.; Wang, J.; Wang, P.; Wang, J.; Yu, J. C. ACS Nano 2014, 8, 8152-8162. doi:10.1021/nn502303h

18. Parmeggiani, C.; Cardona, F. Green Chem. 2012, 14, 547-564. doi:10.1039/c2gc16344f

19. Shi, Z.; Zhang, C.; Tang, C.; Jiao, N. Chem. Soc. Rev. 2012, 41, 3381-3430. doi:10.1039/c2cs15224j

20. Davis, S. E.; Ide, M. S.; Davis, R. J. Green Chem. 2013, 15, 17-45. doi:10.1039/c2gc36441g

21. Wertz, S.; Studer, A. Green Chem. 2013, 15, 3116-3134. doi:10.1039/c3gc41459k

22. Guo, Z.; Liu, B.; Zhang, Q.; Deng, W.; Wang, Y.; Yang, Y. Chem. Soc. Rev. 2014, 43, 3480-3524. doi:10.1039/c3cs60282f

23. Gemoets, H. P. L.; Su, Y.; Shang, M.; Hessel, V.; Luque, R.; Noël, T. Chem. Soc. Rev. 2016, 45, 83-117. doi:10.1039/c5cs00447k

24. Mu, R.; Liu, Z.; Yang, Z.; Liu, Z.; Wu, L.; Liu, Z.-L. Adv. Synth. Catal. 2005, 347, 1333-1336. doi:10.1002/adsc.200505102

25. Karimi, B.; Biglari, A.; Clark, J. H.; Budarin, V. Angew. Chem., Int. Ed. 2007, 46, 7210-7213. doi:10.1002/anie.200701918

26. Jiang, N.; Ragauskas, A. J. ChemSusChem 2008, 1, 823-825. doi:10.1002/cssc.200800144

27. Shibuya, M.; Osada, Y.; Sasano, Y.; Tomizawa, M.; Iwabuchi, Y. J. Am. Chem. Soc. 2011, 133, 6497-6500. doi:10.1021/ja110940c

28. Gowrisankar, S.; Neumann, H.; Gördes, D.; Thurow, K.; Jiao, H.; Beller, M. Chem. - Eur. J. 2013, 19, 15979-15984. doi:10.1002/chem.201302526

29. Karimi, B.; Farhangi, E.; Vali, H.; Vahdati, S. ChemSusChem 2014, 7, 2735-2741. doi:10.1002/cssc.201402059

30. Kim, S. M.; Shin, H. Y.; Kim, D. W.; Yang, J. W. ChemSusChem 2016, 9, 241-245. doi:10.1002/cssc.201501359

31. McCann, S. D.; Stahl, S. S. J. Am. Chem. Soc. 2016, 138, 199-206. doi:10.1021/jacs.5b09940

32. Xie, J.; Yin, K.; Serov, A.; Artyushkova, K.; Pham, H. N.; Sang, X.; Unocic, R. R.; Atanassov, P.; Datye, A. K.; Davis, R. J. ChemSusChem 2017, 10, 359-362. doi:10.1002/cssc.201601364

33. Wei, Z.; Ru, S.; Zhao, Q.; Yu, H.; Zhang, G.; Wei, Y. Green Chem. 2019, 21, 4069-4075. doi:10.1039/c9gc01248f

34. Marzo, L.; Pagire, S. K.; Reiser, O.; König, B. Angew. Chem., Int. Ed. 2018, 57, 10034-10072. doi:10.1002/anie.201709766

35. Kärkäs, M. D.; Porco, J. A., Jr.; Stephenson, C. R. J. Chem. Rev. 2016, 116, 9683-9747. doi:10.1021/acs.chemrev.5b00760

36. Romero, N. A.; Nicewicz, D. A. Chem. Rev. 2016, 116, 10075-10166. doi:10.1021/acs.chemrev.6b00057 
37. Shaw, M. H.; Twilton, J.; MacMillan, D. W. C. J. Org. Chem. 2016, 81 6898-6926. doi:10.1021/acs.joc.6b01449

38. Wang, Q.; Zhang, M.; Chen, C.; Ma, W.; Zhao, J. Angew. Chem., Int. Ed. 2010, 49, 7976-7979. doi:10.1002/anie.201001533

39. Sugano, Y.; Shiraishi, Y.; Tsukamoto, D.; Ichikawa, S.; Tanaka, S.; Hirai, T. Angew. Chem., Int. Ed. 2013, 52, 5295-5299. doi:10.1002/anie.201301669

40. Tanaka, A.; Hashimoto, K.; Kominami, H. J. Am. Chem. Soc. 2012, 134, 14526-14533. doi:10.1021/ja305225s

41. Yurdakal, S.; Palmisano, G.; Loddo, V.; Augugliaro, V.; Palmisano, L. J. Am. Chem. Soc. 2008, 130, 1568-1569. doi:10.1021/ja709989e

42. Chen, Y.-Z.; Wang, Z. U.; Wang, H.; Lu, J.; Yu, S.-H.; Jiang, H.-L. J. Am. Chem. Soc. 2017, 139, 2035-2044. doi:10.1021/jacs.6b12074

43. Meng, C.; Yang, K.; Fu, X.; Yuan, R. ACS Catal. 2015, 5, 3760-3766. doi:10.1021/acscatal.5b00644

44. Furukawa, S.; Shishido, T.; Teramura, K.; Tanaka, T. ACS Catal. 2012, 2, 175-179. doi:10.1021/cs2005554

45. Zhao, L.-M.; Meng, Q.-Y.; Fan, X.-B.; Ye, C.; Li, X.-B.; Chen, B.; Ramamurthy, V.; Tung, C.-H.; Wu, L.-Z. Angew. Chem., Int. Ed. 2017, 56, 3020-3024. doi:10.1002/anie.201700243

46. Guo, R.-Y.; Sun, L.; Pan, X.-Y.; Yang, X.-D.; Ma, S.; Zhang, J. Chem. Commun. 2018, 54, 12614-12617. doi:10.1039/c8cc07137c

47. Nikitas, N. F.; Tzaras, D. I.; Triandafillidi, I.; Kokotos, C. G. Green Chem. 2020, 22, 471-477. doi:10.1039/c9gc03000j

48. Schilling, W.; Riemer, D.; Zhang, Y.; Hatami, N.; Das, S. ACS Catal. 2018, 8, 5425-5430. doi:10.1021/acscatal.8b01067

49. Dongare, P.; MacKenzie, I.; Wang, D.; Nicewicz, D. A.; Meyer, T. J. Proc. Natl. Acad. Sci. U. S. A. 2017, 114, 9279-9283. doi:10.1073/pnas.1707318114

50. Zelenka, J.; Svobodová, E.; Tarábek, J.; Hoskovcová, I.; Boguschová, V.; Bailly, S.; Sikorski, M.; Roithová, J.; Cibulka, R. Org. Lett. 2019, 21, 114-119. doi:10.1021/acs.orglett.8b03547

51. Zhang, Y.; Schilling, W.; Riemer, D.; Das, S. Nat. Protoc. 2020, 15 , 822-839. doi:10.1038/s41596-019-0268-X

52. Sheriff Shah, S.; Pradeep Singh, N. D. Tetrahedron Lett. 2018, 59, 247-251. doi:10.1016/j.tetlet.2017.12.018

53. Su, F.; Mathew, S. C.; Lipner, G.; Fu, X.; Antonietti, M.; Blechert, S.; Wang, X. J. Am. Chem. Soc. 2010, 132, 16299-16301. doi:10.1021/ja102866p

54. Walsh, K.; Sneddon, H. F.; Moody, C. J. Org. Lett. 2014, 16, 5224-5227. doi:10.1021/ol502664f

55. Devari, S.; Rizvi, M. A.; Shah, B. A. Tetrahedron Lett. 2016, 57, 3294-3297. doi:10.1016/j.tetlet.2016.06.046

56. Fukuzumi, S.; Kuroda, S. Res. Chem. Intermed. 1999, 25, 789-811. doi:10.1163/156856799x00680

57. Hu, A.; Guo, J.-J.; Pan, H.; Tang, H.; Gao, Z.; Zuo, Z. J. Am. Chem. Soc. 2018, 140, 1612-1616. doi:10.1021/jacs.7b13131

58. Hu, A.; Guo, J.-J.; Pan, H.; Zuo, Z. Science 2018, 361, 668-672. doi:10.1126/science.aat9750

59. Yatham, V. R.; Bellotti, P.; König, B. Chem. Commun. 2019, 55, 3489-3492. doi:10.1039/c9cc00492k

60. Schwarz, J.; König, B. Chem. Commun. 2019, 55, 486-488. doi:10.1039/c8cc09208g

61. Chen, Y.; Wang, X.; He, X.; An, Q.; Zuo, Z. J. Am. Chem. Soc. 2021, 143, 4896-4902. doi:10.1021/jacs.1c00618

62. Du, J.; Yang, X.; Wang, X.; An, Q.; He, X.; Pan, H.; Zuo, Z. Angew. Chem., Int. Ed. 2021, 60, 5370-5376. doi:10.1002/anie.202012720
63. An, Q.; Wang, Z.; Chen, Y.; Wang, X.; Zhang, K.; Pan, H.; Liu, W.; Zuo, Z. J. Am. Chem. Soc. 2020, 142, 6216-6226. doi:10.1021/jacs.0c00212

64. Zhang, K.; Chang, L.; An, Q.; Wang, X.; Zuo, Z. J. Am. Chem. Soc. 2019, 141, 10556-10564. doi:10.1021/jacs.9b05932

65. Wadekar, K.; Aswale, S.; Yatham, V. R. Org. Biomol. Chem. 2020, 18, 983-987. doi:10.1039/c9ob02676b

66. Shirase, S.; Tamaki, S.; Shinohara, K.; Hirosawa, K.; Tsurugi, H.; Satoh, T.; Mashima, K. J. Am. Chem. Soc. 2020, 142, 5668-5675. doi:10.1021/jacs.9b12918

67. Geibel, I.; Dierks, A.; Müller, T.; Christoffers, J. Chem. - Eur. J. 2017, 23, 7245-7254. doi:10.1002/chem.201605468

68. Speldrich, J.-M.; Christoffers, J. Eur. J. Org. Chem. 2021, 907-914. doi:10.1002/ejoc.202001532

69. Rössle, M.; Werner, T.; Baro, A.; Frey, W.; Christoffers, J. Angew. Chem., Int. Ed. 2004, 43, 6547-6549. doi:10.1002/anie.200461406

\section{License and Terms}

This is an Open Access article under the terms of the Creative Commons Attribution License (https://creativecommons.org/licenses/by/4.0). Please note that the reuse, redistribution and reproduction in particular requires that the author(s) and source are credited and that individual graphics may be subject to special legal provisions.

The license is subject to the Beilstein Journal of Organic Chemistry terms and conditions: (https://www.beilstein-journals.org/bjoc/terms)

The definitive version of this article is the electronic one which can be found at: https://doi.org/10.3762/bjoc.17.121 